Zofia Zarębianka

\title{
NIEPODLEGLOŚĆ DUCHA
}

JAKO WARUNEK WOLNOŚCI

W REFLEKSJI ANTROPOLOGICZNEJ

\section{ORAZ ROZWAŻANIACH KAROLA WOJTYŁY \\ O SZTUCE I ARTYŚCIE}

W aksjologii Karola Wojtyły szczególne miejsce przypada kategorii wolności, która jawi się jako jedna $\mathrm{z}$ niezbywalnych cech człowieczeństwa, wynikających z faktu, iż człowiek został stworzony na obraz i podobieństwo Boga. Wolność w rozumieniu Wojtyły wydaje się też ściśle powiązana z ludzką godnością, której jest wyrazem i przejawem. Pozbawienie człowieka wolności, pozbawienie go możliwości samostanowienia i swobodnego podejmowania decyzji jest uderzeniem w godność człowieka, stanowiąc zakwestionowanie jego podmiotowości i wiąże się z upokorzeniem, będącym też zawsze jakimś naruszeniem granic człowieka i jego godności. Samej zaś godności, jak wiadomo, przypada w antropologii Wojtyły rola pojęcia kluczowego, konstytutywnego dla jego rozumienia człowieka. Wolność pozostaje też u Wojtyły w ścisłym związku z kategorią odpowiedzialności oraz, jak pokazał ks. Andrzej Szostek, z pojęciem uczestnictwa ${ }^{1}$, a także z kategoriami prawdy i dobra, wobec których zawsze powinna się ona konfrontować, gdyż to właśnie prawda i dobro stanowią ostatecznie gwarancję prawdziwości wolności.

Wolność zapiera się samej siebie, zmierza do autodestrukcji i do zniszczenia drugiego człowieka, gdy przestaje uznawać i respektować konstytutywną więź, jaka łączy ją z prawdą. Ilekroć wolność, pragnąc wyswobodzić się od wszelkiej tradycji i autorytetu, zamyka się nawet na pierwotne, najbardziej oczywiste pewniki prawdy obiektywnej i powszechnie uznawanej, stanowiącej podstawę życia osobistego i społecznego,

${ }^{1}$ Por. A. Szostek, Karola Wojtyły koncepcja wolności, [w:] Filozofia chrześcijańska, t. 10, Poznań 2013, s. 47-59. 
wówczas człowiek nie przyjmuje już prawdy o dobru i złu jako jedynego i niepodważalnego punktu odniesienia dla swoich decyzji, ale kieruje się wyłącznie swoją subiektywną i zmienną opinią lub po prostu swym egoistycznym interesem i kaprysem. ${ }^{2}$

Wolność nie jest zatem u Wojtyły brakiem jakichkolwiek ograniczeń i nie polega na całkowitej swobodzie, lecz zawsze powinna być podporządkowana realizowaniu dobra, rozpoznanego jako takie przez rozum i sumienie: „Człowiek jest powołany do wolności. Wolność nie oznacza prawa do samowoli. Wolność nie daje nieograniczonych przywilejów. (...) Człowiek wolny jest przede wszystkim zobowiązany do prawdy (... ”’3. Jest zatem wolność wolnością ku czemuś, wolnością „do”, a nie jedynie wolnością rozumianą negatywnie jako wolność „od”. Trzeba też pamiętać, że wolność w Wojtyłowym systemie wartości posiada kilka wymiarów i aspektów. Z jednej strony, odnosi się i dotyczy pojedynczego człowieka, i ten jej wymiar stanowi fundament dla kolejnego jej wymiaru, a więc, z drugiej strony, dla wolności rozpatrywanej w perspektywie wartości społecznej, politycznej i historycznej odnoszonych do pojęć takich jak naród i państwo. Wolność w odniesieniu do indywidualnej osoby też ujmuje z kolei Wojtyła w dwu aspektach: wolności zewnętrznej, związanej z podejmowanymi przez człowieka działaniami oraz wolności wewnętrznej, związanej z samostanowieniem osoby. W niniejszym szkicu interesować mnie będzie przede wszystkim ostatni z wymienionych rodzajów wolności. Pomijam więc zarówno wolność w odniesieniu do jej wymiaru politycznego i społecznego, jak i ową wolność zewnętrzną warunkowaną konkretnymi czynami i poprzez nie się przejawiającą. Uzasadnieniem dla takiego ujęcia jest wyraźnie obecny w refleksji Wojtyły prymat rozważań o człowieku i punkt ciężkości nakierowany na osobę. Bowiem to przede wszystkim osoba, pojedynczy człowiek i wszystko, co wiąże się z jego egzystencją stanowi w całym jego dziele zasadniczy zwornik zainteresowań Karola Wojtyły - w myśl wyrażonego już w latach papieskich przeświadczenia, iż to człowiek jest drogą Kościoła. Wydaje się zatem, iż w konsekwencji tego rodzaju podejścia bardziej prymarny charakter posiada u Wojtyły namysł nad antropologicznymi, związanymi z pojedynczym człowiekiem aspektami wolności niż refleksja, skądinąd też bardzo istotna, o charakterze społeczno- historycznym czy politycznym. Innymi słowy, uważam, iż pomimo faktu, że rozważania na temat wolności w odniesieniu do społeczności, narodów i państwa zajmują w dziele Karola Wojtyły znaczące miejsce, co widoczne jest

\footnotetext{
${ }^{2}$ Jan Paweł II, enc. Evangelium vitae, p. 19, Zintegrowana Baza Tekstów Papieskich, www. nauczaniejp2.pl/dokumenty (09.2018).

${ }^{3}$ Jan Paweł II, Przemówienie podczas ceremonii pożegnalnej przed Brama Brandenburska, 23.06.1996, Zintegrowana Baza Tekstów Papieskich, www.nauczaniejp2.pl/dokumenty (09.2018).
} 
zwłaszcza w jego nauczaniu papieskim kierowanym do rodaków, czego przykład stanowią choćby następujące, znamienne wielce słowa:

Tu, w tej części Europy, słowo wolność nabiera szczególnego znaczenia. Znamy smak niewoli, smak wojny i niesprawiedliwości. Znają go także te kraje, które przeżyły podobnie jak my tragiczne doświadczenie braku wolności osobistej i społecznej. Dzisiaj cieszymy się z odzyskanej wolności, ale wolności nie można tylko posiadać i używać. Trzeba ją stale zdobywać przez prawdę. Wolność kryje w sobie dojrzałą odpowiedzialność ludzkich sumień, która z tej prawdy wynika. ${ }^{4}$

- to zauważyć się daje, iż choć zacytowane rozważanie dotyczy w głównej mierze wolności w wymiarze wspólnotowym, i tak nacisk zostaje tu położony na osobistą odpowiedzialność i działania pojedynczego człowieka pojmowane jako droga i sposób osiągania wolności w wymiarze wspólnotowym. Fundamentem zatem dla wolności w rozumieniu wolności narodu jest dla Wojtyły ów najbardziej podstawowy wymiar wolności odnoszonej do konkretnego człowieka i świadczącej poprzez kształt podejmowanych przezeń w sumieniu wyborów - o wewnętrznym profilu osoby i o formacie jego człowieczeństwa zadanego mu przez Stwórcę jako dar wymagający odpowiedzialności, współpracy oraz ciągłego rozwoju.

Zdobycie wolności połączonej z odpowiedzialnością jest zadaniem, które musi podjąć każdy człowiek. Dla chrześcijan wolność dzieci Bożych to nie tylko dar i zadanie: jej osiągnięcie jest też bezcennym świadectwem oraz autentycznym wkładem w proces wyzwolenia całego rodzaju ludzkiego. Wyzwolenie to nie ogranicza się do aspektu społecznego i politycznego, gdyż jej najpełniejszym wyrazem jest wolność sumienia (...). ${ }^{5}$

Wszystkie przytoczone cytaty na temat wolności zwracają uwagę tym, iż ujmują ją w pierwszym rzędzie w kategoriach personalistycznych, odnoszonych do egzystencji indywidualnej osoby, do życia pojedynczego człowieka. Ta cecha refleksji Wojtyłowej wydaje się niesłychanie istotna i to dzięki niej przedstawione wyżej koncepcje wolności znajdują zastosowanie także w problemie bardziej partykularnym - mianowicie w odniesieniu do sztuki. Wydaje się bowiem, że realizowaniu tak zarysowanej koncepcji wolności niebagatelna rola przypada w myśleniu Wojtyły kulturze i sztuce, pojmowanym przez niego jako szczególnie uprzywilejowa-

\footnotetext{
${ }^{4}$ Jan Paweł II, Przemówienie podczas spotkania z delegacjami na Międzynarodowy Kongres Eucharystyczny, Wrocław, 01.06.1997, Zintegrowana Baza Tekstów Papieskich, www.nauczaniejp2.pl/ dokumenty (09.2018).

${ }^{5}$ Jan Paweł II, Przemówienie podczas mszy na Placu Rewolucji im. Jose Marti w Hawanie, Hawana 25.01. 1998, Zintegrowana Baza Tekstów Papieskich, www.nauczaniejp2.pl/dokumenty (09.2018).
} 
ny obszar ekspresji wolności, jej zdobywania i poszerzania. Rozumieć to należy na dwa sposoby. Po pierwsze, kultura i sztuka w ujęciu Karola Wojtyły - papieża Jana Pawła II są płaszczyzną, poprzez którą wyraża się, poszerza i buduje wolność, co odnosi się tak do osoby artysty jak i do odbiorcy oraz roli sztuki w jej oddziaływaniu na społeczeństwo. Po drugie zaś, sztuka i kultura wyrastają z wolności, z wolności twórczej, której są wyrazem i owocem. Sztuka wydaje się wręcz domeną wolności, bez której trudno byłoby pomyśleć jakąkolwiek prawdziwą sztukę, i jakiekolwiek prawdziwie artystyczne dzieło. Każde dzieło sztuki pozostaje zatem dla Wojtyły owocem artystycznej wolności i tym samym wyrazem niepodległości ducha twórcy, który tworzy dzieło podporządkowany jedynie idei, którą pragnie wyrazić i wcielić w artystyczną formę dzieła.

Spróbujmy zatem podjąć namysł nad związkami wolności i sztuki w ich rozmaitych aspektach. Najprostszy, najmniej skomplikowany wariant polega na tym, iż sztuka, a szczególności literatura, ale także teatr czy sztuki plastyczne, mogą dostarczać pewnych pozytywnych wzorców osobowych, dzięki którym odbiorca zyskiwałby punkt odniesienia dla własnych działań i wyborów. Model tego rodzaju sztuki wciela romantyzm, z jego ideą tyrteizmu i mesjanizmu. Nie bez powodu wspominam tu o romantycznych wzorcach, gdyż pozostają one bliskie Wojtyłowemu rozumieniu sztuki i w pewnym stopniu wpłynęly na kształt jego koncepcji, zwłaszcza we wczesnym okresie jego własnej twórczości literackiej, co uwidocznia się zwłaszcza w młodzieńczym cyklu zatytułowanym Renesansowy psałterz. W takim jednak wariancie - zwłaszcza jeśli zostanie on uproszczony i strywializowany - kryć się może spore niebezpieczeństwo, polegające na pewnego typu redukcjonizmie, sprowadzającym sztukę i jej zadania do wymiaru pragmatycznego choćby i szlachetnego. Mam więc wrażenie, iż tego rodzaju ujęcie w jakiś sposób deprecjonuje i pomniejsza sztukę, ograniczając jej rolę do swoistego dydaktyzmu czy moralizmu. Z pewnością też nie o takie uproszczone oddziaływanie chodziło Wojtyle - papieżowi Janowi Pawłowi II, gdy przypisywał sztuce istotną rolę w procesie wyzwolenia człowieka. Dokonuje się ono bowiem przede wszystkim poprzez i dzięki doświadczeniu katharsis, umożliwiającemu odbiorcy przekroczenie siebie i doznanie oczyszczenia w zetknięciu z pięknem, dobrem i prawdą zawartymi w dziele artysty. Doświadczenie piękna - choć na chwilę - wyrywa człowieka z jego małości i ograniczeń, ukazując absolutną perspektywę, ku której go prowadzi, w której jest zakorzenione i z której wyrasta. To poszerzanie ludzkiej wrażliwości dokonujące się w kontakcie z pięknem w konsekwencji czyni człowieka bardziej wolnym, pozwalając mu na odnalezienie w sobie jakichś nici wiążących go $\mathrm{z}$ absolutnym dobrem i absolutnym pięknem, w których ma udział każde cząstkowe piękno wytworzone ręką, sercem i umysłem człowieka. Wydaje się, iż istotną rolą sztuki w rozumieniu Wojtyły jest swego rodzaju „zapalenie” człowieka do dobra, wytworzenie pewnej iskry, a w konsekwencji wyzwolenie w nim potrzeby dobra - 
realizowanego we własnym życiu dzięki obcowaniu ze sztuką, która w takim ujęciu dostarczałaby jakichś istotnych inspiracji do stawania się lepszym, do poznawania siebie poprzez konfrontację z prezentowanymi w sztuce postawami. Z drugiej strony, ów związek sztuki z wolnością uwidocznia się również jako intymna przestrzeń wewnętrzna twórcy oraz - co wydaje się niezmiernie ważne - jako twórczy imperatyw. W pierwszym rzędzie chodzi tu o wymóg wewnętrznej wolności, gwarantującej bezinteresowność aktu twórczego i jego niezależność od jakichkolwiek koniunkturalnych uwarunkowań, od których twórca winien być w jak największym stopniu wolny, a jednocześnie świadom niebezpieczeństw tego rodzaju zagrożenia. Koniunkturalizm byłby swego rodzaju zniewoleniem artysty, podporządkowującym jego twórcze działania oczekiwaniom czy to władzy, czy to środowiska, a także mody, obowiązujących konwencji czy też wreszcie warunkującemu kształt dzieła kwestiami wynagrodzenia, zależnego od spełnienia czyichś wyobrażeń estetycznych. Od tego rodzaju czynników artysta musi pozostać wolny, inaczej grozi mu zaprzedanie siebie i zaprzedanie swego dzieła oraz oddanie siebie w taką czy inną niewolę możnych tego świata. Zagadnienie wewnętrznej wolności artysty wiąże się też z innego rodzaju zagrożeniami czy wręcz pokusami, generowanymi przez chęć zaistnienia w środowisku i osiągnięcia w nim określonej, wysokiej pozycji. Chodzi w tym wypadku o umiejętność oparcia się potrzebie niezdrowej rywalizacji, zachowania dystansu do siebie i swoich wytworów oraz rezygnację z postawy nieustannego porównywania się z innymi, prowadzącego do frustracji oraz - tak czy inaczej - do pychy, bądź to przejawiającej się w postaci wywyższania się i przekonania o własnej doskonałości artystycznej, bądź to w postaci nieuprawnionego pomniejszania swojej wartości. Tego rodzaju mechanizmy odbierają artyście jako człowiekowi jego wewnętrzną wolność, krępując ją i niszcząc jego autonomię - tak autonomię artysty jak i, co gorsza, autonomię ludzką i podporządkowując ją rozmaitym czynnikom i oddziaływaniom zewnętrznym. Postulowana przez Karola Wojtyłę zarówno w Rekolekcjach dla artystów jak i w papieskim już Liście do artystów bezinteresowność jawi się przeto i może być rozpatrywana jako przejaw wewnętrznej wolności, stojącej u podstaw owej bezinteresowności i ją warunkującej. Innymi słowy, bez wewnętrznej wolności wskazywana przez Wojtyłę jako pożądana czy wręcz niezbędna cecha moralna artysty w postaci bezinteresowności wydaje się niemożliwa. Bezinteresowność twórcy, bezinteresowność aktu twórczego uznać też można za wyraz hojności serca, pragnącego dzielić się z odbiorcą posiadanym przez twórcę niematerialnym dobrem. W tym miejscu znów pojawia się kwestia zdolności do rozpoznania przez twórcę dobra i decyzji o jego wyborze. Chodzi zatem o odpowiedzialność artysty za kształt tego, co tworzy i za jakość treści przekazywanych za pośrednictwem dzieła. Na ten aspekt ludzkiej odpowiedzialności twórcy za przesłanie zawarte w dziele, Wojtyła kładzie ogromny nacisk w obydwu 
przywołanych wyżej tekstach. W formie artystycznej na ten sam problem zwraca też uwagę Czesław Miłosz, gdy w wierszu Ars poetica napomina:

Bo wiersze wolno pisać rzadko i niechętnie.

Pod nieznośnym przymusem i tylko z nadzieją,

Że dobre, nie złe duchy mają w nas instrument.

Wydaje się, iż chodzi tu o dwie sprawy, ściśle zresztą z sobą połączone. strony najpierw więc o świadomość twórcy - „czemu, komu służy”, czy wybierane przezeń wartości najogólniej rzecz biorąc budują dobro i poszerzają jego horyzont w świecie. Nastepnie, czy poprzez tworzenie sam artysta „rośnie” w swoim człowieczeństwie, za kształt którego jest odpowiedzialny przed Stwórcą. To pytanie dla Wojtyłowego myślenia o sztuce i artyście wręcz kluczowe, wskazujące na obecność w jego refleksji personalistycznego prymatu nad wszelkimi innymi zagadnieniami. Pytanie o dobro człowieka, o dobro osoby - oczywiście w kontekście Bożej prawdy nadają rozważaniom Wojtyły o sztuce rys głębokiej egzystencjalnej powagi. Sztuka, akt twórczy nie jest bowiem dla niego sferą gry, zabawy czy eksperymentu, lecz są jakimś szczególnym uczestnictwem w dziele samego Boga. Stąd też, jak się wydaje, ów nacisk na etyczny wymiar tak samego aktu twórczego, rozumianego w perspektywie ludzkiego czynu, jak i na etyczny kształt dzieła, którego uzasadnieniem ma być ostatecznie - niekoniecznie wprost - ukazywanie absolutnego horyzontu ludzkich dziejów i przeznaczeń. Stąd też, jak wolno sądzić, wynika ów szczególnie mocny związek kwestii wolności i twórczości w refleksji Wojtyły - Jana Pawła II na temat sztuki i artysty. Skoro bowiem tworzenie jest uczestnictwem w dziele stwórczym Boga, a Bóg jest w sposób absolutny wolny, to na mocy faktu, iż człowiek stworzony został na obraz i podobieństwo Boga oraz nosi w sobie jakiś Boski pierwiastek, Boską iskrę przynależną do jego istoty, to twórcze działanie człowieka, także powinno czy wręcz musi wynikać z wolności, wyrażać ją i ku niej - w różnych płaszczyznach prowadzić. Z jednej zatem strony, twórca - na wzór Stwórcy pielęgnować w sobie musi ów pierwiastek wolności, gwarantujący jego prawdziwą podmiotowość i upodabniającą jego artystyczne działanie do gestu kreacyjnego Boga, z drugiej zaś strony, owa wolność musi w koncepcji Wojtyły pozostawać zawsze pod kontrolą sumienia, sprawdzającego czemu, jakim wartościom, artysta jest wierny, w jaki sposób wykorzystuje tę swoją twórczą wolność. Wolny, nieskrępowany akt twórczy nie tylko stanowi wyraz kreatywności człowieka, ale też pozostaje związany z samostanowieniem osoby, wskazując na osiągnięte przez nią samo posiadanie, niezwykle istotne dla wewnętrznej wolności i będące jedną z jej oznak. W taki sposób akt twórczy - w ujęciu Karola Wojtyły - wpisuje się w budowanie człowieczeństwa artysty i staje się istotnym elementem jego wewnętrznej formacji. 
W klasycznym postępowaniu oceniającym dzieło, wypracowanym jeszcze przez Tomasza z Akwinu, uznaje się niezależność wartości dzieła od wartości moralnej twórcy. Reguła ta z pewnością jest do dziś obowiązująca w odniesieniu do dzieła. W myśleniu jednak Karola Wojtyły o kwestii wartości dzieła pojawia się jeszcze inna, dodatkowa perspektywa, uwzględniająca nie tylko wytwór, nie tylko efekt twórczego działania artysty, ale też jego samego, biorąca przeto pod uwagę podmiotowość twórcy jako artysty i jako człowieka. W takim ujęciu maksymalistyczny postulat doskonałości skierowany zostaje nie tylko na dzieło, ale także na podmiot czynności twórczych, który ma poprzez tworzenie, poprzez pracę nad dziełem stawać się pełniejszym, lepszym człowiekiem, ma dzięki pracy twórczej szlifować nie tylko przedmiot artystyczny, ale i własną duszę, własne człowieczeństwo. To zaś zagadnienie w sposób ścisły wiąże się z pytaniem o kierunek wykorzystywania przez artystę swojej wolności. Inaczej można by to pytanie sformułować następująco: czy wolność artysty zostaje ostatecznie podporządkowana miłości i czy rządzi tą wolnością sumienie, w świetle którego artysta bada tak dzieło jak i swoje własne intencje?

Skoro jednak wolność w antropologii Wojtyły i w jego refleksji o sztuce i artyście nie jest nigdy wolnością bez ograniczeń, lecz pozostaje ukierunkowana w stronę dobra i w stronę miłości, oznacza to, iż niekiedy wyrazem najwyższej wolności może okazać się rezygnacja z tworzenia, rezygnacja z czynnego uprawiania i sztuki i reorientacja życiowych aktywności na rzecz takich działań, które w sumieniu rozpoznaje się jako służące większemu dobru. Mam tu szczególnie na myśli postać św. Brata Alberta, ukazanego przez Wojtyłę w jego dramacie Brat naszego Boga w procesie dojrzewania do decyzji o porzuceniu sztuki w imię służby najuboższym, w których to rozpoznaje cierpiącego Chrystusa. Postać Adama Chmielowskiego fascynowała Wojtyłę, a przeżywane przez niego dylematy tak głęboko przedstawione w utworze odzwierciedlały własne rozterki młodego Karola stojącego przed decyzją o wyborze życiowej drogi. Wyrzeczenie dokonane przez bohatera sztuki może być potraktowane jako gest najwyższej wolności, podporządkowanej miłości oraz wewnętrznej prawdzie postaci, która - by pozostać w zgodzie z sobą i w zgodzie z własnym sumieniem nie tyle odrzuca sztukę, ile przekracza ją, by w sposób bardziej bezpośredni podążać drogą naśladowania Mistrza z Nazaretu, w przekonaniu, iż tylko tak, rezygnując z bycia malarzem i oddając się całkowicie ubogim, będzie mógł wydobyć w sobie w najpełniejszy sposób złożone w nim podobieństwo do Chrystusa i najlepiej zrealizować swoje powołanie.

Wydaje się, iż w rozważaniu o związku wolności i sztuki w refleksji Karola Wojtyły/papieża Jana Pawła II nie może zabraknąć omówionego wyżej wariantu, w którym to wyrzeczenie i rezygnacja jawią się jako owoc wolności ukierunkowanej na wcielanie swoim życiem miłości. 
Ostatecznie tė̇, w przypadku każdego powołania życiowego, nie tylko powołania artysty chodzi o takie właśnie praktykowanie wolności, które prowadziłoby do owego magis - „więcej”, ujrzanego jako wezwanie do realizowania dobra. Pozostaje też ono najgłębszym uzasadnieniem wszelkiej sztuki i każdego aktu twórczego - poprzez które człowiek według Karola Wojtyły - ma bardziej stawać się człowiekiem, a przez to urzeczywistniać w sobie podobieństwo do Stwórcy.

\section{Abstract \\ Independence of the spirit as a condition of freedom in anthropological reflection and considerations of Karol Wojtyła on art and artist}

The text is an attempt to show that in the axiology of Karol Wojtyła, the category of freedom occupies a special place, which appears as one of the inalienable features of humanity, resulting from the fact that man was created in the image and likeness of God. Freedom, as understood by Wojtyła, also seems to be closely related to human dignity, of which it is an expression and manifestation. Depriving a man of his freedom, depriving him of the possibility of self-determination and free decision making is a blow to human dignity, challenging his subjectivity and is associated with humiliation, which is also always a violation of man's limits and dignity. As it is known, dignity, in Wojtyła's anthropology, plays the role of a key concept, constitutive of his understanding of human.

Keywords: axiology, antropology, freedom, philosophy, Wojtyła. 